\author{
Шалений В.А. \\ старший викладач \\ кафедра управління бізнесом \\ Одеська національна академія харчових технологій \\ вул. Канатна, 112, м. Одеса, Україна, 65039 \\ E-mail: shalenyy@i.ua
}

\title{
ОЦІНКА РІВНЯ РИЗИКОВАНОСТІ ДІЯЛЬНОСТІ ПІДПРИЄМСТВ ХЛІБОПЕКАРСЬКОЇ ПРОМИСЛОВОСТІ В ДОВГОСТРОКОВОМУ ПЕРІОДІ
}

Проаналізовані підходи до оцінки ризикованості діяльності підприємств та запропонований авторський підхід до проведення оцінки рівня довгострокового ризику на основі аналізу системи показників групи підприємств. Апробація методики була проведена на основі даних фрінансової звітності дев'ятнадцяти підприємств хлібопекарської промисловості України: оцінений рівень їх довгострокового ризику, проведене відповідне ранжування підприємств та визначені основні напрямки їх розвитку в контексті розв'язання проблеми мінімізації рівня ризикованості діяльності.

Ключові слова: оцінка ризиків, управління ризиками, промисловість, ризикоутворюючиий чинник, чинник-симптом, рівень ризику.

This work is licensed under a Creative Commons Attribution 4.0 International License http://creativecommons.org/licenses/by/4.0/

Постановка проблеми та її зв'язок з важливими науковими та практичними завданнями. Успішне функціонування сучасного підприємства можливе лише за умови побудови якісної системи менеджменту. Ця система має забезпечувати ефективність діяльності усіх ланок відповідно до загальних цілей підприємства. Знаходячись у ринкових умовах, усі сфери діяльності підприємства, його внутрішнє та зовнішнє середовище, постійно перебуває під впливом різноманітних ризиків, які в свою чергу можуть істотним чином вплинути на його функціонування. Нажаль, сьогодні управління ризиками на більшості підприємств не вважається однією 3 функцій менеджменту або видом діяльності та відбувається на «інтуїтивному» рівні. Не дивлячись на те, що для таких видів діяльності, як інвестиційна та фінансова вже накопичений достатній досвід управління ризиками, в цілому, ризики, властиві підприємствам промисловості як високоорганізованим виробничим системам, недостатньо вивчені, а отже, і відсутні адекватні механізми управління ними.

Отже, побудова системи управління ризиками промислових підприємств, вбудованої в загальний менеджмент підприємства, $є$ на сьогоднішній день безумовним чинником ефективного функціонування суб'єкта господарювання в довгостроковій перспективі.

Аналіз останніх публікацій по проблемі. Основні теоретичні аспекти оцінки та управління ризиками розглядаються у фундаментальних роботах А. Сміта [1], Ф.Х. Найта [2], Й. Шумпетера [3]. Серед сучасних зарубіжних економістів, що досліджують проблему ризику у підприємництві, можна відзначити Е. Холмса [4], К Ерроу [5], А.П. Альгіна [6], I.T. Балабанова [7], А.Г. Бадалову [8]. Визначення ризику та характеристика методів управління ним знайшли відображення і в роботах українських економістів: І.Ю. Івченко [9], В.В. Вітлінського [10], В.М. Гранатурова [11], В.В. Лук'янової [12] та інших. Слід однак зауважити, що більшість досліджень реалізують окремо короткострокове або довгострокове прогнозування ризиків. Процеси ідентифікації, прогнозування та управління цими ризиками мають відмінності між собою, на що звертається мало уваги в сучасному ризик-менеджменті.

Отже, на сьогоднішній день виключну актуальність має розробка та впровадження методики оцінки та управління ризиками підприємств харчової промисловості як виробничих систем в короткому та довгому періоду 3 подальшим узгодженням отриманих результатів.

Формулювання цілей дослідження. Метою дослідження $\epsilon$ розробка методичних підходів та оцінка рівня довгострокового ризику діяльності хлібопекарських підприємств.

Виклад основних результатів та їх обгрунтування. В сучасному ризик-менеджменті під ризиками виробничої системи розуміється подія або дія, група подій або дій, які стосуються функціонування і розвитку виробничої системи і настання яких пов'язане $з$ відхиленнями в реалізації розробленої стратегії та фінансових результатів діяльності виробничої системи від прогнозованих, очікуваних або запланованих. Негативні відхилення в реалізації розробленої стратегії можна розуміти як отримання негативних фінансових результатів в довгостроковому періоді. Отже, реалізація зазначених вище ризиків призводить до отримання негативних фінансових результатів в короткостроковому та довгостроковому періодах. 
Далі зупинимося на процесі управління ризиками підприємств харчової промисловості саме в довгостроковому періоді. Враховуючи те, що зазначені ризики реалізуються знижуючи прибуток підприємства, їх дослідження доцільно проводити використовуючи у якості головного індикатору абсолютні та відносні показники прибутковості.

При проведенні досліджень дії ризиків на діяльність підприємств на нашу думку необхідно акцентувати головну увагу не на абстрактних ризиках, а на потенційній можливості підприємства стабільно розвиватися в умовах невизначеності та агресивного зовнішнього середовища, тобто в умовах постійно діючих ризиків, склад та сила впливу яких на підприємство змінюється. Таким чином, управління ризиками можна розглядати як забезпечення здатності системи (підприємства) протистояти негативному впливу внутрішнього та зовнішнього середовища (дії ризикоутворюючих чинників), та використовувати ринкові можливості, які містять ознаки невизначеності, для підвищення ефективності діяльності та конкурентоспроможності. Таким чином, дослідження впливу ризиків на діяльність підприємства та, відповідно, визначення його здатності успішно функціонувати в таких умовах, $є$ латентною (прихованою) ознакою підприємства, а отже можна говорити про відсутність можливості прямого кількісного визначення зазначеної ознаки підприємства [13].

Дослідження наукових підходів до оцінки рівня латентних ознак підприємств дає підстави стверджувати, що оцінку рівня «здатності підприємства як виробничої системи успішно функціонувати в умовах ризику» можна провести за допомогою методів таксономічного аналізу, засобів кластерного та дискримінантного аналізу з подальшим поглибленим дослідженням чинників-симптомів за допомогою факторного аналізу. В якості основних чинників-симптомів здатності підприємства успішно функціонувати в умовах ризику пропонується використовувати абсолютні та відносні показники прибутковості діяльності, а також статистичні характеристики, які описують динаміку зазначених показників. Для оцінки рівня визначеної вище латентної ознаки підприємства пропонується використання наступних показників:

- абсолютна маса прибутку від операційної діяльності;

- рівень рентабельності продажів, розрахований за прибутком від операційної діяльності;

- середній абсолютний приріст прибутку від операційної діяльності за період дослідження;

- кількість прибуткових періодів (років) за період дослідження.

Отримання якісних результатів оцінки ризиків в довгостроковому періоді передбачає використання значного масиву вихідної інформації, а саме репрезентативної вибірки 3 представників галузі (ринку), по кожному з яких має бути сформований динамічний ряд з відповідними показниками за тривалий період часу. Визначення рівня довгострокового ризику як рівня відповідної латентної ознаки підприємства вимагає отримання однозначної оцінки кож- ного чинника-симптому. 3 огляду на те, що вихідна інформація по першим двом показникам представляється у вигляді динамічного та варіаційного рядів, виникає необхідність попередньої статистичної обробки значень цих показників, а саме згортання рівнів динамічних рядів. При згортанні динамічних рядів важливо не втратити інформацію про об'єкт, яку несе кожний 3 їх рівнів. Якщо припустити, що функція корисності значень рівнів динамічного ряду є монотонно зростаючою від найбільш віддаленого у часі до найменш віддаленого відносно моменту проведення оцінки, розрахунок значень прибутку від операційної діяльності та рентабельності продажів, які будуть використовуватись для отримання загальної оцінки рівня довгострокового ризику, можна провести за формулою:

$$
\mathrm{Xn}_{\mathrm{z} E}=\sum_{i=1}^{t} \mathrm{Xn}_{i} \leqslant \mathrm{~d}_{i}
$$

де $\mathrm{X} n_{\mathrm{z}}$ - зважене значення чинникасимптому по n-му об'єкту.

$\mathrm{X} n_{-}$- фактичне значення чинника-симптому по n-му об'єкту в t-му році;

$d_{\mathrm{i}}$ - коефіцієнт корисності фактичного значення чинника-симптому в $\mathrm{t}$-му році для оцінки довгострокового ризику $\left(\sum_{i=1}^{t} d_{i}=1\right)$.

Розрахунок коефіцієнтів корисності доцільно проводити, на нашу думку, за відповідною формулою Фішберна:

$$
d_{i}=\frac{2 * i}{t *(t+1)}
$$

де $\mathrm{t}$ - кількість років у періоді дослідження (кількість спостережень).

i - порядковий номер року (спостереження).

Значення третього чинника-симптому (середній абсолютний приріст прибутку від операційної діяльності за період дослідження) може бути визначене як коефіцієнт регресії при чиннику часу у лінійній моделі тренду.

Останнім чинником-симптомом, який пропонується використовувати для оцінки довгострокового ризику, є кількість прибуткових років протягом періоду дослідження. Даний показник, на відміну від трьох попередніх $є$ дискретним та не потребує попередньої статистичної обробки.

Подальший розрахунок рівня довгострокового ризику передбачає згортання значень окремих чинників-симптомів в інтегральний показник, що вимагає стандартизації значень показників:

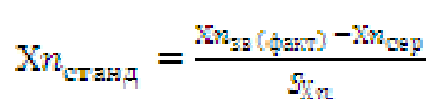

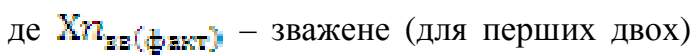
або фактичне (для останніх двох) значення чинникасимптому;

$\mathrm{X} n_{\text {сер }}$ - середнє арифметичне зважених або фактичних значень чинників-симптомів;

$S_{\text {жn }}$ - стандартне відхилення зважених або фактичних значень чинників-симптомів. 
3 огляду на те, що отримані значення показників є центрованими, та з урахуванням неможливості компенсації одного чинника-симптому іншим, інтегральне значення показника довгострокового ризику доцільно визначати за допомогою адитивної моделі:

$$
R_{\text {iнterv }}=\sum_{k=1}^{4} \mathrm{Xn}_{\mathrm{crang}} \mathrm{k}^{2}
$$

Останнім етапом оцінки є розпізнавання рівня довгострокового ризику за допомогою шкалювання інтегрального показника $R_{\text {iнтегp }}$.

Розпізнавання рівня довгострокового ризику пропонується виконувати за допомогою сигмоїди (Sподібної кривої), безумовною перевагою якої $\epsilon$ підвищена здатність до розпізнавання значень, які знаходяться усередині сукупності. 3 урахуванням припущення про нормальність розподілу чинниківсимптомів та інтегрального показника довгострокового ризику, або розподіл, близький до нормального, а також проведення стандартизації значень чинниківсимптомів, використання S-подібної кривої, а саме зворотної логістичної регресії, $\epsilon$ найбільш доречним.

Отже, рівень довгострокового ризику визначатиметься за формулою:

$$
R_{\text {доEए }}=1-\frac{1}{1+\theta^{R i n e r y}}
$$

Для характеристики рівня ризику у зрозумілих для загального менеджменту підприємства термінах може бути запропонована наступна його градація:

- мінімальний ризик ( $\boldsymbol{R}_{\text {дов }}$ менше 0,2$)$;

- прийнятний ризик $\left(\boldsymbol{R}_{\text {довг }}\right.$ від 0,2 до 0,4$)$;

- високий ризик $\left(\boldsymbol{R}_{\text {давг }}\right.$ від 0,4 до 0,6$)$;

- загрозливий ризик $\left(R_{\text {дәгг }}\right.$ від 0,6 до 0,75$)$;

- критичний ризик $\left(R_{\text {довг }}\right.$ від 0,75 до 0,9$)$;

- катастрофічний ризик $\left(R_{\text {zosг }}\right.$ більше 0,9$)$.
Нерівномірна градація рівня ризику (починаючи із загрозливого) є наслідком нерівномірного впливу загального ризику на діяльність підприємства та його потенційною мультиплікацією (лавиноподібним зростанням).

Для оцінки рівня довгострокового ризику підприємств хлібопекарської промисловості, тобто визначення здатності підприємств галузі протистояти негативному впливу дії ризикоутворюючих чинників та використовувати ринкові можливості, які містять ознаки невизначеності, для підвищення ефективності діяльності та конкурентоспроможності була досліджена діяльність дев'ятнадцяти підприємств за період 2009-2016 роки [14]. На першому етапі на основі даних фінансової звітності підприємств були сформовані динамічні та варіаційні ряди прибутку від операційної діяльності підприємств (X1) та визначені значення рентабельності продажів (X2) як відношення прибутку від операційної діяльності до чистого доходу від операційної діяльності.

Згортання рівнів динамічних рядів прибутку від операційної діяльності та рентабельності продажів проводилося за формулою (1), для чого були використані коефіцієнти корисності фактичного значення чинника-симптому в t-му році $\left(d_{i}\right)$, розраховані за формулою (2).

Середній абсолютний приріст прибутку від операційної діяльності (X3), який також формує рівень довгострокового ризику, був визначений як відповідний коефіцієнт регресії (при факторі часу t) рівняння тренду, побудованого по лінійній моделі. Розрахунок параметрів моделі проведений в Excel за допомогою вбудованої функції ЛИНЕЙН та наведений в табл.1.

Таблиця 1

Визначення показників (чинників-симптомів) рівня довгострокового ризику хлібопекарських підприсмств України*

\begin{tabular}{|l|c|c|c|c|c|}
\hline \multicolumn{1}{|c|}{ Підприємство } & Х1зв & Х2зв & $\begin{array}{c}\text { Лінійне рівняння тренду для } \\
\text { прибутку від операційної } \\
\text { діяльності }\end{array}$ & Х3 & Х4 \\
\hline $\begin{array}{l}\text { 1. ПрАТ "Дніпропетровський хлібозавод } \\
\text { №9" }\end{array}$ & 2515,2 & 1,87 & $\mathrm{y}=-100,5+872,4 * \mathrm{t}$ & 872,4 & 5 \\
\hline 2. ПрАТ "Дрогобицький хлібокомбінат" & 674,0 & 3,24 & $\mathrm{y}=17,4+228,1 * \mathrm{t}$ & 228,1 & 6 \\
\hline 3. ПрАТ "Ізяславський хлібозавод" & 3202,3 & 8,69 & $\mathrm{y}=-325,6+278,1 * \mathrm{t}$ & 278,1 & 8 \\
\hline 4. ПАТ "Київхліб" & 33173,4 & 1,56 & $\mathrm{y}=51776,8-2015,5 * \mathrm{t}$ & $-2015,5$ & 6 \\
\hline 5. ПрАТ "Концерн Хлібпром" & 63335,8 & 7,83 & $\mathrm{y}=12012,3+11861,5 * \mathrm{t}$ & 11861,5 & 8 \\
\hline 6. ПрАТ "Конотопський хлібокомбінат" & 730,3 & 2,98 & $\mathrm{y}=263,6+29,4 * \mathrm{t}$ & 29,4 & 8 \\
\hline 7. ПАТ "Козятинхліб" & 671,5 & 1,44 & $\mathrm{y}=715,9+157,5 * \mathrm{t}$ & 157,5 & 5 \\
\hline 8. ПАТ "Коростенський хлібозавод" & $-1922,6$ & $-5,24$ & $\mathrm{y}=4895,9-309,4 * \mathrm{t}$ & $-309,4$ & 0 \\
\hline 9. ПАТ "Криворіжхліб" & 539,6 & 0,57 & $\mathrm{y}=3591,5+125,8 * \mathrm{t}$ & $-125,8$ & 4 \\
\hline 10. ПрАТ "Люботинський хлібозавод" & 574,9 & $-0,70$ & $\mathrm{y}=731,7+396,6 * \mathrm{t}$ & 396,6 & 4 \\
\hline 11. ПАТ "Нікопольський хлібокомбінат" & $-1262,8$ & $-3,00$ & $\mathrm{y}=4232,7-10,8 * \mathrm{t}$ & $-10,8$ & 2 \\
\hline 12. ПАТ "Новоград-Волинський хлібозавод" & 2732,4 & 5,64 & $\mathrm{y}=-358,2+341,9 * \mathrm{t}$ & 341,9 & 8 \\
\hline 13. ПАТ "Овруцький хлібозавод" & 26,3 & 0,37 & $\mathrm{y}=484,4-57,9 * \mathrm{t}$ & $-57,9$ & 5 \\
\hline 14. ПАТ "Олевський хлібозавод" & 160,3 & 1,71 & $\mathrm{y}=1201,8-107,0 * \mathrm{t}$ & $-107,0$ & 6 \\
\hline 15. ПрАТ "Славутський хлібозавод" & 2431,4 & 5,89 & $\mathrm{y}=-644,1+354,3 * \mathrm{t}$ & 354,3 & 8 \\
\hline 16. ПрАТ "Торецький хлібокомбінат" & 325,1 & 1,31 & $\mathrm{y}=467,9-33,8 * \mathrm{t}$ & $-33,8$ & 8 \\
\hline
\end{tabular}


Продовження табл.1

\begin{tabular}{|l|c|c|c|c|c|}
\hline Підприємство & Х1зв & Х2зв & $\begin{array}{c}\text { Лінійне рівняння тренду для } \\
\text { прибутку від операційної } \\
\text { діяльності }\end{array}$ & Х3 & Х4 \\
\hline $\begin{array}{l}\text { 17. ПрАТ "Харківський хлібокомбінат "Сло- } \\
\text { божанський" }\end{array}$ & $-7111,8$ & $-17,77$ & $\mathrm{Y}=15082,5-1750,1 * \mathrm{t}$ & $-1750,1$ & 0 \\
\hline 18. ПАТ "Хліб" & 137,1 & 0,30 & $\mathrm{Y}=1203,9-95,3 * \mathrm{t}$ & $-95,3$ & 7 \\
\hline 19. ПрАТ "Шосткинський хлібокомбінат" & 1033,5 & 3,96 & $\mathrm{Y}=2256,1-299,1 * \mathrm{t}$ & $-299,1$ & 8 \\
\hline Середнє значення & 5366,63 & 1,09 & - & 511,32 & 5,58 \\
\hline Стандартне відхилення & 16079,30 & 5,69 & - & 2832,30 & 2,63 \\
\hline
\end{tabular}

* розраховано автором

Останнім показником (чинникомсимптомом), який визначає рівень довгострокового ризику у запропонованій моделі, є кількість прибуткових років протягом періоду дослідження. Даний показник не потребує додаткової статистичної обробки та наведений в таблиці 1. В таблиці також наведені основні статистичні показники варіаційних рядів чинників-симптомів, які використовуються для стандартизації значень останніх.

В табл. 2 наведемо розрахунок стандартизованих значень показників моделі оцінки довгострокового ризику $\left(\mathrm{Xn}_{\text {станд }}\right)$ за формулою (3), а також інте-

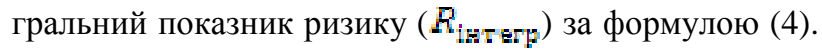

Таблиця 2

Визначення стандартизованих значень показників рівня довгострокового ризику*

\begin{tabular}{|c|c|c|c|c|c|}
\hline Підприємство & Х1станд & Х2станд & ХЗстанд & Х4станд & Rінтегр \\
\hline 1. ПрАТ "Дніпропетровський хлібозавод №9" & $-0,177$ & 0,137 & 0,127 & $-0,220$ & $-0,133$ \\
\hline 2. ПрАТ "Дрогобицький хлібокомбінат" & $-0,292$ & 0,379 & $-0,100$ & 0,160 & 0,147 \\
\hline 3. ПрАТ "Ізяславський хлібозавод" & $-0,135$ & 1,337 & $-0,082$ & 0,920 & 2,040 \\
\hline 4. ПАТ "Київхліб" & 1,729 & 0,083 & $-0,892$ & 0,160 & 1,080 \\
\hline 5. ПрАТ "Концерн Хлібпром" & 3,605 & 1,186 & 4,007 & 0,920 & 9,719 \\
\hline 6. ПрАТ "Конотопський хлібокомбінат" & $-0,288$ & 0,334 & $-0,170$ & 0,920 & 0,795 \\
\hline 7. ПАТ "Козятинхліб" & $-0,292$ & 0,062 & $-0,125$ & $-0,220$ & $-0,574$ \\
\hline 8. ПАТ "Коростенський хлібозавод" & $-0,453$ & $-1,112$ & $-0,290$ & $-2,120$ & $-3,976$ \\
\hline 9. ПАТ "Криворіжхліб" & $-0,300$ & $-0,090$ & $-0,225$ & $-0,600$ & $-1,215$ \\
\hline 10. ПрАТ "Люботинський хлібозавод" & $-0,298$ & $-0,315$ & $-0,041$ & $-0,600$ & $-1,253$ \\
\hline 11. ПАТ "Нікопольський хлібокомбінат" & $-0,412$ & $-0,719$ & $-0,184$ & $-1,360$ & $-2,676$ \\
\hline 12. ПАТ "Новоград-Волинський хлібозавод" & $-0,164$ & 0,801 & $-0,060$ & 0,920 & 1,498 \\
\hline 13. ПАТ "Овруцький хлібозавод" & $-0,332$ & $-0,127$ & $-0,201$ & $-0,220$ & $-0,880$ \\
\hline 14. ПАТ "Олевський хлібозавод" & $-0,324$ & 0,110 & $-0,218$ & 0,160 & $-0,272$ \\
\hline 15. ПрАТ "Славутський хлібозавод" & $-0,183$ & 0,845 & $-0,055$ & 0,920 & 1,527 \\
\hline 16. ПрАТ "Торецький хлібокомбінат" & $-0,314$ & 0,039 & $-0,192$ & 0,920 & 0,453 \\
\hline 17. ПрАТ "Харківський хлібокомбінат "Слобожанський" & $-0,776$ & $-3,317$ & $-0,798$ & $-2,120$ & $-7,011$ \\
\hline 18. ПАТ "Хліб" & $-0,325$ & $-0,138$ & $-0,214$ & 0,540 & $-0,137$ \\
\hline 19. ПрАТ "Шосткинський хлібокомбінат" & $-0,269$ & 0,504 & $-0,286$ & 0,920 & 0,869 \\
\hline
\end{tabular}

* розраховано автором

При проведенні дослідження важливим $\epsilon$ оцінка взаємних зав'язків та залежностей між показниками (чинниками-симптомами) розробленої моделі. 3 цією метою проведемо кореляційний аналіз за- значених показників (за їх стандартизованими значеннями). Кореляційна матриця показників моделі оцінки довгострокового ризику наведена в табл.3.

Таблиця 3

Кореляційна матриця чинників-симптомів моделі оцінки довгострокового ризику*

\begin{tabular}{|c|c|c|c|c|}
\hline & $\mathrm{X} 1$ & $\mathrm{X} 2$ & $\mathrm{X} 3$ & $\mathrm{X} 4$ \\
\hline $\mathrm{X} 1$ & 1,000 & & & \\
\hline $\mathrm{X} 2$ & 0,395 & 1,000 & & \\
\hline $\mathrm{X} 3$ & 0,793 & 0,411 & 1,000 & \\
\hline $\mathrm{X} 4$ & 0,321 & 0,848 & 0,298 & 1,000 \\
\hline
\end{tabular}


Як свідчать значення коефіцієнтів парної кореляції, наведені в таблиці, існує досить сильна попарна залежність між факторами X1 та X3, а також X2 та X4. 3 урахуванням тієї обставини, що фактори X1 та X2 є первинними, а також з огляду на відсутність відчутної залежності між ними, про що свідчить низьке значення коефіцієнта парної кореляції, можна констатувати наявність значних обмежень в можливостях підприємств забезпечувати високий рівень абсолютної та відносної прибутковості одночасно. Таким чином, можна виділити два базові напрямки зниження довгострокового ризику, тобто підвищення здатності підприємства ефективно функціонувати в умовах ризику:

- орієнтація на максимальну суму прибутку, що для більшості підприємств галузі може бути досягнуто лише за рахунок виконання виробничої програми зі значною питомою вагою масової продукції з відповідним низьким рівнем рентабельності.

- орієнтація на максимальну рентабельність продажів, що можливе за рахунок виробництва продукції з відносно високим рівнем рентабельності, попит на яку значно менший, ніж на масову продукцію.

Основною ознакою першої загальної стратегії $є$ те, що вона дозволяє більш динамічно розвиватися (нарощувати масу прибутку), про що говорить сильний зв'язок між масою прибутку від операційної діяльності (X1) та середнім абсолютним приростом прибутку (X3), але в цілому не є стабільною з точки зору отримання прибутків, тобто характеризується підвищеним рівнем ризикованості. Така стратегія вимагає висококваліфікованого менеджменту та наявності значних резервів фінансової стійкості підприємства, тобто підвищених вимог щодо структури капіталу та абсолютних величин його елементів, насамперед, власних джерел коштів, що $\epsilon$ вирішальним чинником подолання можливої короткострокової збитковості.

Друга стратегія дозволяє підприємствам знизити вірогідність збитків, про що свідчить високе значення коефіцієнта кореляції між рентабельністю продажів (X2) та кількістю прибуткових періодів (X4), але не є чинником формування довгострокових переваг, оскільки не забезпечує довгострокового позитивного тренду прибутковості.

Таким чином, можна констатувати, що маса прибутку від операційної діяльності порівняно з рентабельністю продажів є більш інертним, тобто «важким» чинником забезпечення прибутковості в довгострокового періоді (зниження довгострокового ризику), з відповідними перевагами та недоліками (можливості щодо керування, гнучкість, витратність тощо).

Останнім етапом оцінки довгострокового ризику підприємств $є$ розпізнавання довгострокового ризику по формулі (5).

В таблиці 4 наведені результати розпізнавання довгострокового ризику у вигляді показника оцінки $R_{\text {довг }} 3$ відповідною його градацією по видам та визначені рейтинги підприємств за рівнем довгострокового ризику від найменшого (1) до найбільшого (19).

Таблиця 4

Оцінка рівня довгострокового ризику хлібопекарських підприсмств України

\begin{tabular}{|l|c|c|c|}
\hline \multicolumn{1}{|c|}{ Підприємство } & $\begin{array}{c}\text { Iнтегральний } \\
\text { показник } \\
\text { довгостроко- } \\
\text { вого ризику } \\
\text { (Riнтегр) }\end{array}$ & $\begin{array}{c}\text { Рівень } \\
\text { довго- } \\
\text { го ризоково- } \\
\text { (Rдовг) }\end{array}$ & Вид ризику \\
Рейтинг \\
підприєм- \\
ства
\end{tabular}


Аналіз даних, наведених в таблиці, дає підстави зробити висновок, що в дослідженій сукупності хлібопекарських підприємств беззаперечним лідером є один з провідних виробників - ПрАТ «Концерн Хлібпром», довгостроковий ризик діяльності якого майже відсутній. Показники, наведені в таблиці 2, говорять про відсутність слабких сторін зазначеного підприємства. Підприємство стало єдиним з усієї вибірки, яке змогло забезпечити одночасно високу абсолютну та відносну прибутковість діяльності. Слід відзначити, що інше підприємство, яке також займає одну $з$ лідируючих позицій на ринку хліба - ПАТ «Київхліб», має середній рівень довгострокового ризику $(0,254)$ та займає п'яту позицію в рейтингу за показником довгострокового ризику. Однією з основних слабких сторін підприємства $€$ значна чутливість до системних ризиків, оскільки значне погіршення показників ефективності функціонування та збитковість його операційної діяльності були зафіксовані в 2014-2015 роках, тобто в період загальної економічної, фінансової та політичної кризи. Збитковість діяльності в цей період стала основною причиною негативного тренду прибутковості діяльності (показник Х3) та відповідно вплинула на загальний рівень довгострокового ризику (Rдовг). Окрім ПрАТ «Концерн Хлібпром» мінімальний рівень довгострокового ризику мають такі підприємства, як ПрАТ "Ізяславський хлібозавод" (Rдовг = 0,115), ПрАТ "Славутський хлібозавод" (Rдовг = 0,178) та ПАТ "НовоградВолинський хлібозавод" (Rдовг $=0,183)$. Зазначені підприємства мають схожі ознаки довгострокового ризику (рівні чинників-симптомів), а саме високий рівень рентабельності продажів при відносно незначній абсолютній масі прибутку та характеризуються прибутковістю діяльності протягом усього періоду дослідження (табл. 1). Таким чином, ефективність функціонування зазначених підприємств пов'язана 3 використанням другої базової стратегії мінімізації довгострокового ризику, тобто надання переваги при плануванні виробничої програми насамперед рентабельним видам продукції. Більшість досліджуваних об'єктів мають середній (4 підприємства) та високий (4 підприємства) рівень ризику, і потребують більш детального дослідження ризикованості діяльності на основі засобів кластерного та факторного аналізу. Два підприємства (ПАТ "Криворіжхліб" та ПрАТ "Люботинський хлібозавод") мають критичний рівень ризику. Усі чинники-симптоми (табл. 2) мають від'ємні значення, тобто підприємства показують гірші результати, ніж в середньому по галузі та не мають жодної переваги перед конкурентами. Основна причина такого становища підприємств вбачається у вкрай неефективному загальному менеджменті підприємств. Останні три позиції в рейтингу займають підприємства 3 катастрофічним рівнем ризику: ПАТ "Нікопольський хлібокомбінат" (Rдовг = 0,936), ПАТ "Коростенський хлібозавод" (Rдовг = 0,982), ПрАТ "Харківський хлібокомбінат "Слобожанський" (Rдовг = 0,999). Підприємства характеризуються вкрай низькими показниками ефективності діяльності, і якщо ПАТ "Нікопольський хлібокомбінат" має шанси на врятування за умови зміни менеджменту та прийняття якнайскоріших жорстких антикризових заходів, (умовний оптимізм щодо майбутнього підприємства пояснюється здатністю підприємства генерувати прибуток взагалі (протягом двох років з восьми (загальний період дослідження) періодів операційна діяльність підприємства була прибутковою)), то ПАТ "Коростенський хлібозавод" та ПрАТ "Харківський хлібокомбінат "Слобожанський" майже повністю позбавлені шансів щодо подальшого функціонування як хлібопекарські підприємства, оскільки протягом усього періоду дослідження в жодному році не були прибутковими, тобто як виробничі системи в сучасному вигляді не здатні генерувати прибуток.

Висновки та перспективи подальших досліджень. Аналіз сучасних підходів до визначення рівня ризику в довгостроковому періоді свідчить, що в більшості випадків під ним розуміється оцінка загрози банкрутства, що провадиться на основі порівняння розрахованого показника 3 відповідними нормативними значеннями. В роботі запропонований власний підхід до проведення оцінки на основі аналізу системи показників групи підприємств 3 наступним відповідним ранжуванням їх за рівнем ризикованості діяльності. Особливістю підходу є отримання оцінки рівня довгострокового ризику на основі аналізу конкурентного середовища.

Кореляційний аналіз чинників-симптомів рівня довгострокового ризику дозволив виділити дві базові стратегії управління рівнем довгострокового ризику та поведінки підприємств в конкурентному середовищі, а саме орієнтація на максимальну суму прибутку, що для більшості підприємств галузі може бути досягнуто лише за рахунок виконання виробничої програми зі значною питомою вагою масової продукції з відповідним низьким рівнем рентабельності, або орієнтація на максимальну рентабельність продажів, що можливе за рахунок виробництва продукції з відносно високим рівнем рентабельності, попит на яку значно менший, ніж на масову продукцію.

\section{Література}

1. Смит А. Исследование о природе и причинах богатства народов (книги 1-3) / А. Смит. - М. : Эксмо, 2016. - 1056 c.

2. Найт Ф.Х. Риск, неопределенность и прибыль / Ф.Х. Найт. - М.: Дело, 2003. - 360 с.

3. Шумпетер Й. Теория экономического развития (исследование предпринимательской прибыли, капитала, кредита, процента и цикла конъюнктуры) / Й. Шумпетер. - М.: Прогресс, 1982. - 456 с.

4. Холмс Э. Риск-менеджмент / Э. Холмс. - М.: Эксмо, 2007 - 312 с. 
5. Эрроу К.Д. Восприятие риска в психологии и экономической науке [Электронный ресурс]. - Режим доступа: //http://ecsocman.edu.ru/db/msg/90877.html

6. Альгин А.П. Грани экономического риска / А.П. Альгин. - М.: Знание, 1994. - 264 с.

7. Балабанов И.Т. Риск-менеджмент / И.Т. Балабанов. - М. : Финансы и статистика, 1996. - 192 с.

8. Бадалова А.Г. Управление рисками производственных систем: теория, методология, механизмы реализации: [монографія] / А.Г. Бадалова. - М.: «Станкин», «ЯНУС-К», 2006. - 328 с.

9. Івченко І.Ю. Економічні ризики / І.Ю. Івченко. - К.: Центр навчальноі літератури, 2004. - 304 с.

10. Вітлінський В.В. Економічний ризик і методи його вимірювання / Вітлінський В.В., Наконечний С.І., Шарапов О.Д. - К.: ІЗМН, 1996. - 400 с.

11. Гранатуров В.М. Экономический риск: сущность, методы измерения, пути снижения / В.М. Гранатуров. - М. : Дело и сервис, 2002. - 160 с.

12. Лук'янова В.В. Економічний ризик / В.В. Лук'янова, Т.В. Головач. - К. : Академвидав, 2007. - 464 с.

13. Янковий О.Г. Латентні ознаки в економіці: [монографія] / О.Г. Янковий. - О.: Атлант, 2015. - 168 с.

Стаття надійшла 29.10.2017

Стаття прийнята до друку 13.11.2017

Доступно в мережі Internet 30.12.2017

\author{
Шаленый В.А. \\ старший преподаватель \\ кафедра управления бизнесом \\ Одесская национальная академия пищевых технологий \\ ул. Канатная, 112, г. Одесса, Украина, 65039 \\ E-mail: shalenyy@i.ua
}

\title{
ОЦЕНКА УРОВНЯ РИСКА ДЕЯТЕЛЬНОСТИ ПРЕДПРИЯТИЙ ХЛЕБОПЕКАРНОЙ ПРОМЫШЛЕННОСТИ В ДОЛГОСРОЧНОМ ПЕРИОДЕ
}

В статье проанализированы основные современные методические подходы к оценке уровня долгосрочного риска. Установлено, что оценка долгосрочных рисков, под которой в большинстве случаев понимается определение угрозы банкротства, осуществляется на основе сравнения рассчитанного показателя с соответствующими нормативными значениями. Такие модели являются жесткими и не учитывают текущего состояния внешней среды, особенностей отрасли (рынка), уровня деловой активности, действия системных рисков и т.д. Это требует проведения процедуры адаптации указанных моделей или построения новых, более гибких, оценка рисков по которым будет строиться на основе анализа конкурентной среды объекта оценки. В статье автором предложен собственный подход к проведению оценки уровня долгосрочного риска на основе анализа системы показателей (факторов-симптомов) группы предприятий с последующим соответствующим ранжированием и группировкой их по уровню рискованности деятельности. Шкалирование уровня долгосрочного риска целесообразно проводить с помощью обратной логистической регрессии, особенностью которой является повышенная способность к распознаванию значений, находящихся внутри совокупности. Апробация методики была проведена на основе данных финансовой отчетности девятнадцати предприятий хлебопекарной промышленности: оценен уровень их долгосрочного риска, проведено соответствующее ранжирование предприятий и определены основные направления их развития в контексте решения проблемы минимизации уровня риска деятельности.

Корреляционный анализ факторов-симптомов уровня долгосрочного риска позволил выделить две базовые стратегии управления уровнем долгосрочного риска и поведения предприятий в конкурентной среде, а именно ориентация на максимальную сумму прибыли, что для большинства предприятий может быть достигнуто только за счет выполнения производственной программы со значительным удельным весом массовой продукции с низким уровнем рентабельности, или ориентация на максимальную рентабельность продаж, что возможно за счет производства продукции с относительно высоким уровнем рентабельности, спрос на которую значительно меньше, чем на массовую.

Ключевые слова: оценка рисков, управления рисками, промышленность, рискообразующий фактор, фрактор-симптом, уровень риска. 


\author{
Shaleny V.A. \\ Assistant \\ Department of Management of Business \\ Odessa National Academy of Food Technologies \\ Kanatna str., 112, Odesa, Ukraine, 65039 \\ E-mail: shalenyy@i.ua
}

\title{
ESTIMATION OF THE RISK LEVEL OF THE ACTIVITY AT THE BAKING INDUSTRY ENTERPRISES IN LONG-TERM PERIOD
}

The article analyzes the main modern methodological approaches to assessing the level of long-term risk. It has been established that the evaluation of long-term risks, which in most cases means the definition of the threat of bankruptcy, is performed on the basis of comparison of the calculated indicator with the corresponding normative values. Such models are rigid and do not take into account the current state of the external environment, the characteristics of the industry (market), the level of business activity, the effect of systematic risks, etc. This requires carrying out the procedure for adapting of these models or building new, more flexible ones, the risk assessment will be based on the analysis of the competitive environment of the valuation object. The author suggests his own approach to the assessment of the level of long-term risk on the basis of the analysis of the system of indicators (factor-symptoms) of a group of enterprises with subsequent appropriate ranking and grouping them according to the level of activity riskness. Scaling of the level of long-term risk is advisable to carry out with the help of reverse logistic regression, the feature of which is the increased ability to recognize the values that are inside the aggregate. Approbation of the methodology was carried out on the basis of the financial records data of nineteen enterprises of the baking industry: the level of their long-term risk was assessed, the corresponding ranking of enterprises was carried out and the main directions of their development were determined in the context of solving the problem of minimizing the level of activity risk.

The correlation analysis of the long-term risk factor symptoms made it possible to identify two basic strategies for managing the level of long-term risk and enterprise behavior in a competitive environment, namely, the orientation toward the maximum amount of profit, which for most enterprises can be achieved only through the implementation of the production program with a significant share of the mass products with a low level of profitability, or orientation to the maximum profitability of sales, which is possible due to the production of products with a relatively high level of profitability, the demand for which is much less than for the mass one.

Keywords: estimation of risks, management risks, industry, risk factor, factor-symptom, risk level.

\section{References}

1. Smit, A. (2016). Issledovanie o prirode i prichinah bogatstva narodov (Knigi 1-3). Moskva: Eksmo.

2. Nayt, F. H. (2003). Risk, neopredelennost i pribyil. Moskva: Delo.

3.Shumpeter, Y. (1982). Teoriya ekonomicheskogo razvitiya (issledovanie predprinimatelskoy pribyili, kapitala, kredita, protsenta i tsikla kon'yunkturyi. M.: Progress.

4. Holms, E. (2007). Risk-menedzhment. Moskva: Eksmo.

5. Errou, K. D. (1994). Vospriyatie riska v psihologii i ekonomicheskoy nauke. Retrieved from //http://ecsocman.edu.ru/db/msg/90877.html

6. Algin, A. P. (1994). Grani ekonomicheskogo riska. M.: Znanie.

7. Balabanov, I. T. (1996). Risk-menedzhment. M.: Finansyi i statistika.

8. Badalova, A. G. (2006). Upravlenie riskami proizvodstvennyih sistem: teoriya, metodologiya, mehanizmyi realizatsii. M.: «Stankin», «YaNUS-K».

9. Ivchenko, I. Iu. (2004). Ekonomichni ryzyky. K.: Tsentr navchalnoi literatury.

10. Vitlinskyi, V. V., Nakonechnyi, S. I., \& Sharapov, O. D. (1996). Ekonomichnyi ryzyk i metody yoho vymiriuvannia. K.: IZMN.

11. Granaturov, V. M. (2002). Ekonomicheskiy risk: suschnost, metodyi izmereniya, puti snizheniya. M.: Delo i servis.

12. Luk'ianova, V. V., \& Holovach, T. V. (2007). Ekonomichnyi ryzyk. K.: Akademvydav.

13. Yankovyi, O. H. (2015). Latentni oznaky v ekonomitsi. O.: Atlant. 